Baseline

\title{
Freshwater lenses as ecological and population sustenance, case study in the coastal wetland of Samborombón Bay (Argentina)
}

\author{
Carolina Tanjal $^{\mathrm{a}, *}$, Eleonora Carol $^{\mathrm{a}, \mathrm{b}}$, Sebastián Richiano ${ }^{\mathrm{a}, \mathrm{b}}$, Lucía Santucci ${ }^{\mathrm{a}, \mathrm{b}}$ \\ a Centro de Investigaciones Geológicas, Consejo Nacional de Investigaciones Científicas y Técnicas, Diag. 113 no. 275, 1900 La Plata, Argentina \\ b Facultad de Ciencias Naturales y Museo, Universidad Nacional de La Plata, Argentina
}

\section{A R T I C L E I N F O}

\section{Keywords:}

Hydrogeomorphological units

Hydrogeochemistry

Water resources

Ecosystemic services

RAMSAR site

\begin{abstract}
A B S T R A C T
Freshwater lenses associated to shell ridges and sand sheets exist on the coastal wetland of Samborombón Bay. As they constitute one of the most vulnerable aquifer systems, it is the aim of this study to determine the hydrogeochemical processes that condition the chemical quality of its groundwater and to assess their present and future capability as sustenance of native woods and local villagers. To achieve this, hydrogeomorphological field surveys were made and groundwater samples were taken. Results show that lenses have a mean thickness of $12 \mathrm{~m}$ and its chemical quality depends on the dissolution of $\mathrm{CO}_{2(\mathrm{~g})}$ and carbonates, weathering of silicates and ion exchange. Lenses can be affected by long-term climatic variability and mining. The study of morphology and geochemistry of the freshwater lenses bring lights into important information about the management of water resources and conservation of the environment.
\end{abstract}

Coastal wetlands are located in a critical interface between land and sea environments where they constitute one of the most productive and valuable regions of the world providing many ecosystem goods and services (Odum and Harvey, 1988). The rational management of these areas is a particular challenge as they are sensitive environments for which any change in the quantity, quality and water flow, has the potential to fundamentally affect the integrity of the ecosystem (Fletcher et al., 2011). Most of these wetlands are developed in coastal plain areas of clayey silt sediments formed during sea level oscillations in the Quaternary where shallow groundwater tends to be saline (Carol et al., 2009). Shell ridges are geoforms genetically associated to coastal plains where the positive morphology and higher permeability of its sandy sediments favors rainwater infiltration and freshwater lenses formation (Maas, 2007; De Louw et al., 2011). The presence of freshwater lenses in coastal wetlands dominated by saline groundwater enables the existence of particular ecosystems and, on the other hand, secures the water supply for the local villagers. Their limited extension and topography determines that they are one of the most vulnerable aquifer systems in the world (Morgan and Werner, 2014) due to easily salinized by natural (sea level arise) or anthropic processes (intensive exploitation).

The Ajó coastal plain (Fig. 1) on the Samborombón Bay coastland (Argentina) comprises an extensive wetland designated as a RAMSAR site in 1997. The groundwater within the coastal plain and associated marsh is saline with values that reach $30.29 \mathrm{mg} / \mathrm{L}$ (Carol et al., 2009;
Carol et al., 2016). Within the plain, shell ridges are developed in the northern and central sector of the wetland where the freshwater lenses are harbored (Carol et al., 2010). These lenses form a particular environment within the wetland that not only is the sustenance to protected native species like the Celtis tala forest, also constitute the only source of potable water for the local people. The objectives of this paper are to determine the geochemical and hydrological processes that condition the chemical quality of groundwater in the freshwater lenses and to assess the present and future capability of the lenses as sustenance of native woods and local villagers.

In order to characterize the fresh water lenses, a water balance for the period 2015-2016 was carried out by means of monthly temperature and rainfall data (Thornthwaite and Mather, 1957). At the same time, we made a water balance for a more extended period (1960-2016) to determine excess and deficit water periods for the study area. A hydrological and geomorphological characterization of the units that harbor the freshwater lenses within the coastal plain was achieved on the basis of background data, the analysis of satellite images and topographic maps and field surveys.

A regional monitoring network was created with 29 sampling points, among mills and household wells (ca. $12 \mathrm{~m}$ depth), shallow exploration wells ( $4 \mathrm{~m}$ depth) and abandoned quarries where the water table arises (Fig. 1). The data analyzed correspond to the sampling collected in September 2016. At the central sector of the bay, a monitoring network at a local level was carried out in order to define

\footnotetext{
* Corresponding author.

E-mail address: ctanjal@cig.museo.unlp.edu.ar (C. Tanjal).
} 

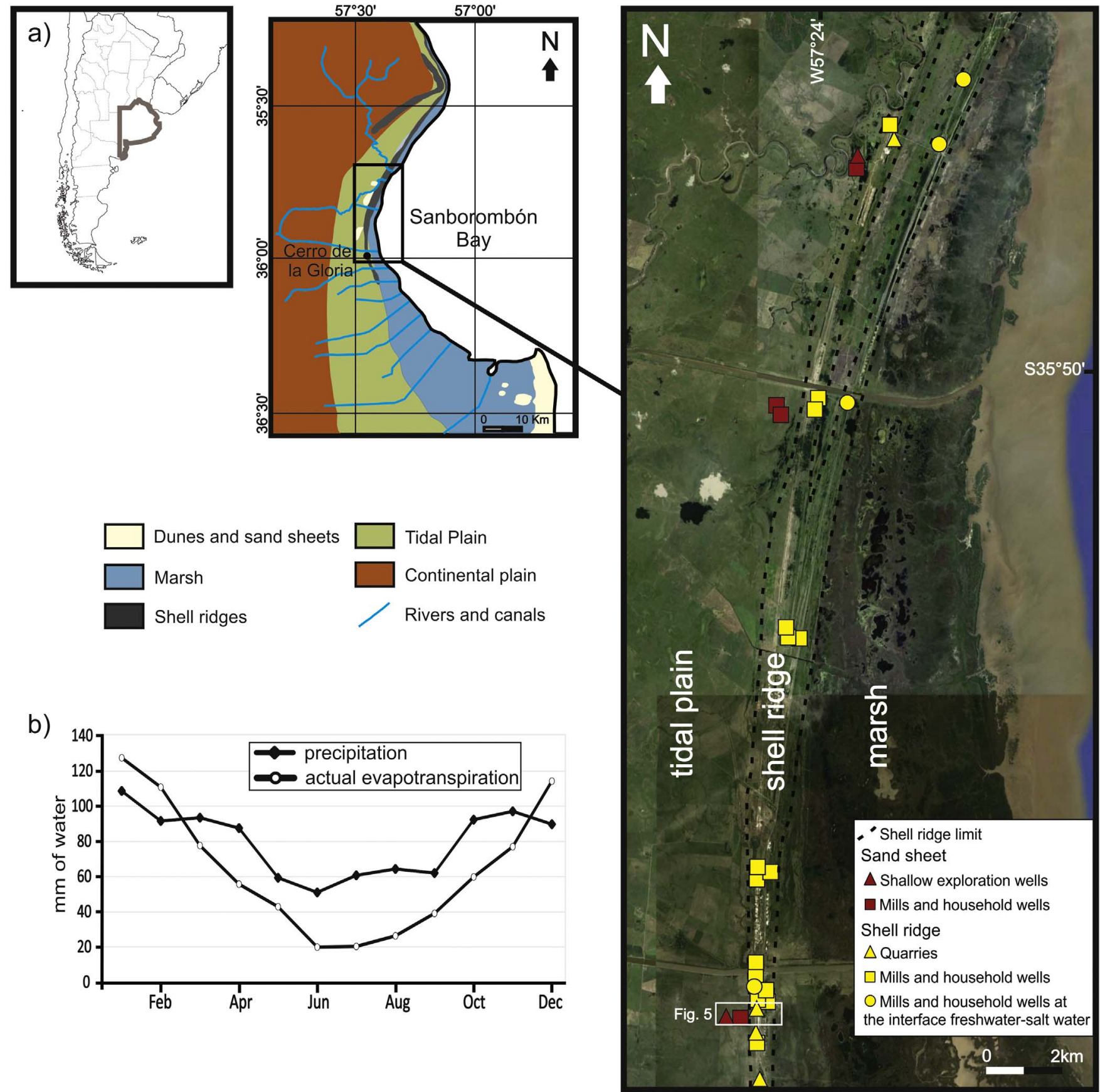

b)

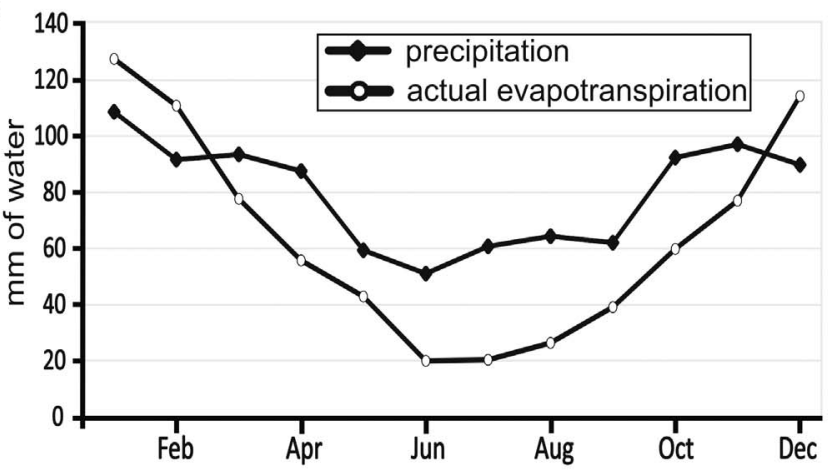

Tidal Plain
Continental plain

Rivers and canals

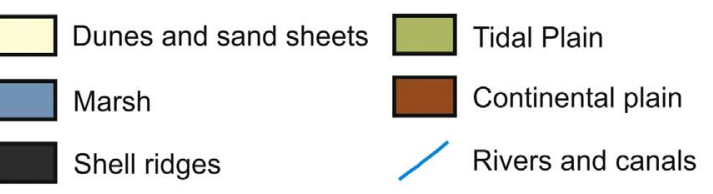




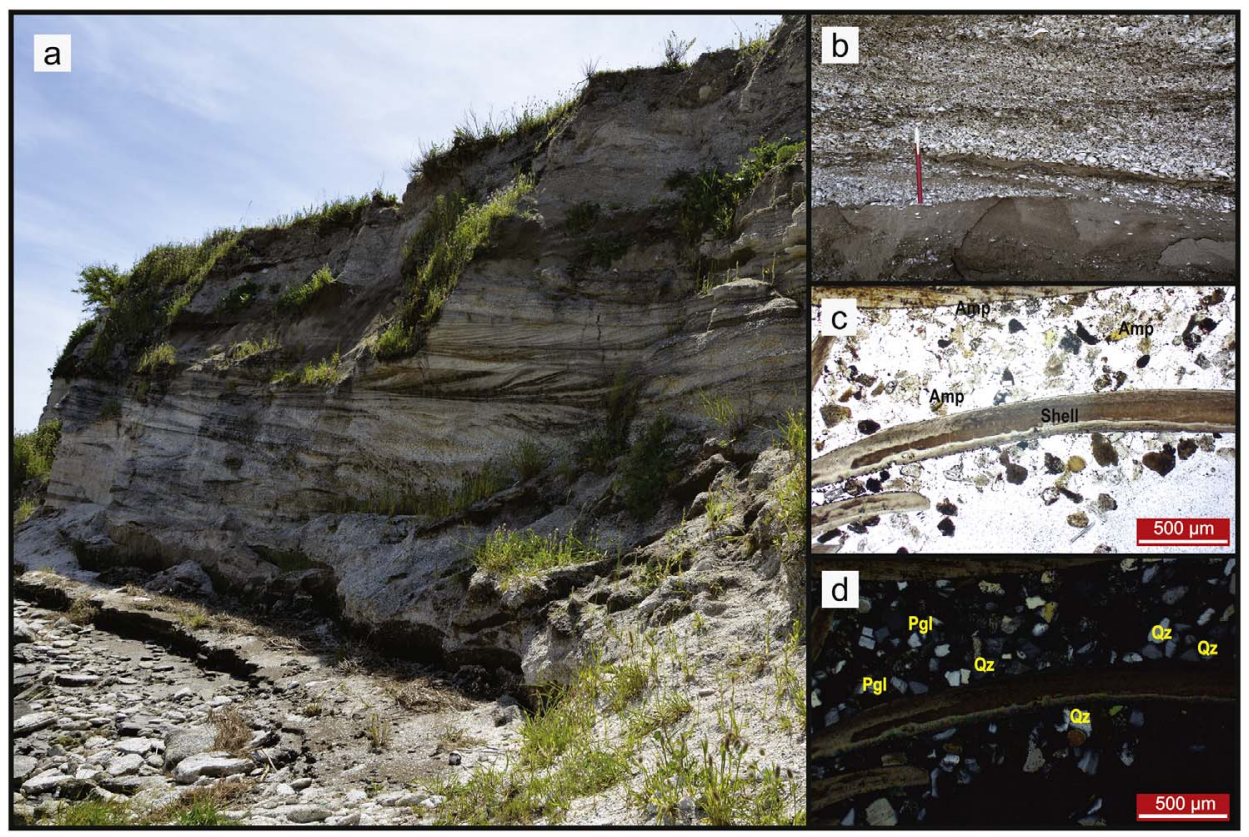

Fig. 2. Photo of the shell ridge: a) lateral wall after excavation; b) image a) close up; Sand fraction of the shell ridge under the polarization microscope (c and d).

evapotranspiration, while between December and February the evapotranspiration predominates.

Within the low permeability sediments of the coastal plain, two high-permeability hydrogeomorphological units are recognized. These units are capable of accumulate the rains surpluses in the shape of lenses. The first one is the shell ridge, which arranged parallel to the current coastline with a 50-120 m width, approximately $10 \mathrm{~km}$ length and about 7.5 m.a.s.l. height. They are mainly composed by shell fragments with a sandy matrix (quartz, plagioclase, secondary calcite, volcanic glass, mafics like hornblende) and subordinated smectite clay minerals (Fig. 2). These materials are not distributed homogeneously, generating that the ridge has two different sectors, a shell-ridge to the east and a sand-ridge to the west. The second hydrogeomorphological unit is the sand sheets located at the west of the ridges. They have subcircular to elongated morphologies reaching heights up to 5 m.a.s.l. They are composed by quartzitic fine-grained sands, scarce shell fragments and subordinated clay at the bottom.

Measurements of groundwater salinity of these two hydrogeomorphological units evidence the presence of low salinity water with values mainly below $2000 \mu \mathrm{S} / \mathrm{cm}$. Some of the samples extracted from deeper wells or the ones located at the ridges or sand sheets boundaries show higher salinities with values reaching $10,000 \mu \mathrm{S} / \mathrm{cm}$. The chemical analysis of the major ions reflects that there are differences between the groundwater in the ridges and sand sheets, as well as between shallow and deeper wells within each unit. In the ridge, samples extracted from mills and household wells (ca. $12 \mathrm{~m}$ depth) located at the central sector of the ridge are sodium bicarbonate type (Fig. 3), with $\mathrm{pH}$ values between 7.47 and 8.93 while the electrical conductivity (EC) varies from 570 to $1931 \mu \mathrm{S} / \mathrm{cm}$. The $\mathrm{Na}^{+} / \mathrm{Cl}^{-}$ionic ratio presents a very wide range of values, from 2.11 to 48.4 with $\mathrm{Cl}^{-}$values lower than $6 \mathrm{meq} / \mathrm{L}$ in all cases (Fig. 4a, b). The $\mathrm{Na}^{+}$excesses with values between 2.52 and $16.03 \mathrm{meq} / \mathrm{L}$ are related to similar $\mathrm{Ca}^{2+}$ and $\mathrm{Mg}^{2+}$ deficiencies (Fig. $4 \mathrm{~b})$ with a ratio close to $1: 1$. The negative SI calcite $(-1.08$ to -0.11 ) denotes undersaturation of this mineral (Fig. 4c), indicating that an increase in $\mathrm{HCO}_{3}{ }^{-}$and $P_{\mathrm{CO} 2}$ does not produce large variations in the calcite saturation (Fig. 4c, d). The clays stability graph shows that all the samples are in equilibrium with Ca-montmorillonite type clay (Fig. 4e).

In those wells located at the marginal zones of the ridge or that take water from a greater depth, water is sodium chloride type with slightly

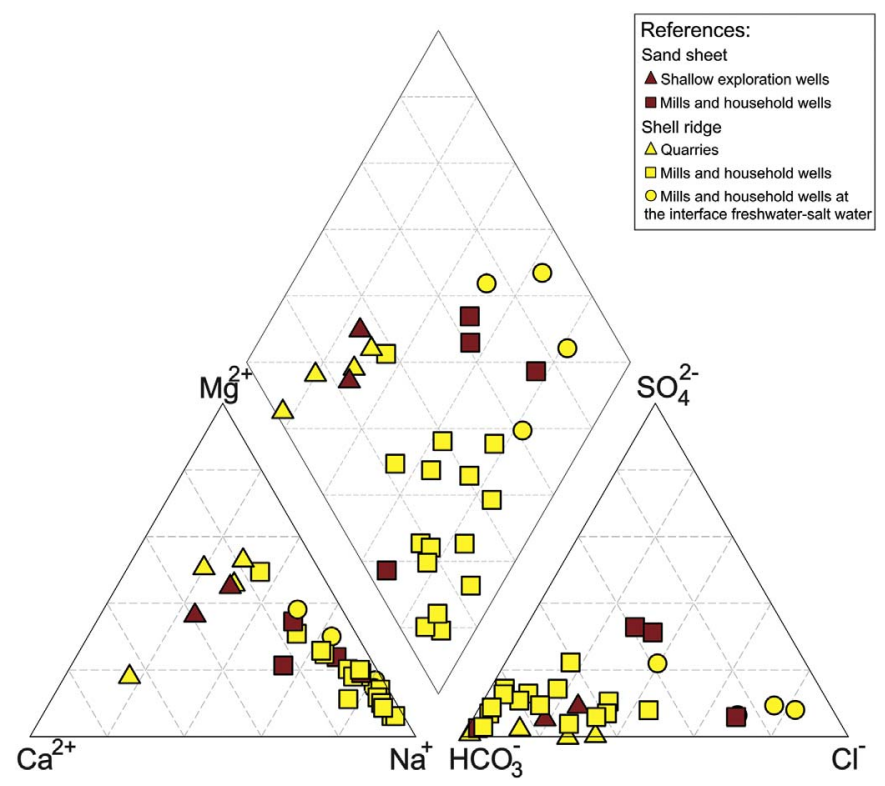

Fig. 3. Piper diagram for water sample classification.

alkaline $\mathrm{pH}$ and electrical conductivities reaching values up to $10,600 \mu \mathrm{S} / \mathrm{cm}$ (Fig. 3). In the $\mathrm{Na}^{+} / \mathrm{Cl}^{-}$ratio versus $\mathrm{Cl}^{-}$an increase in the $\mathrm{Cl}^{-}$content associated with hardly variable low $\mathrm{Na}^{+} / \mathrm{Cl}^{-}$values (1-2.51) is observed (Fig. 4a). Two samples show $\mathrm{Na}^{+}$excesses related to deficiencies in $\mathrm{Ca}^{2+}$ and $\mathrm{Mg}^{2+}$ with values close to $20 \mathrm{meq} / \mathrm{L}$, whereas in the other two are lower than $3 \mathrm{meq} / \mathrm{L}$ (Fig. 4b). All of them evidence an undersaturation of calcite, except in one with greater salinity, which is oversaturated (0.35) (Fig. 4c, d). Calcite saturation indexes register both positive and negative values near to the equilibrium state of 0 values. In turn, as indicated in Fig. 4e, the clay mineral associated to the water composition is Ca-montmorillonite.

Regarding water in the abandoned quarries, it is highly alkaline $\mathrm{pH}$ close to 10) calcium bicarbonate type with very low electrical conductivity that do not exceed $300 \mu \mathrm{S} / \mathrm{cm}$ (Fig. 3). $\mathrm{Na}^{+}$lightly dominates against $\mathrm{Cl}^{-}$with $\mathrm{Na}^{+} / \mathrm{Cl}^{-}$ratio between 2.02 and 11.26 and slightly excesses of $\mathrm{Na}^{+}$are also related to $\mathrm{Ca}^{2+}$ and $\mathrm{Mg}^{2+}$ deficiencies (Fig. 4a, b). The most undersatured values of calcite are 

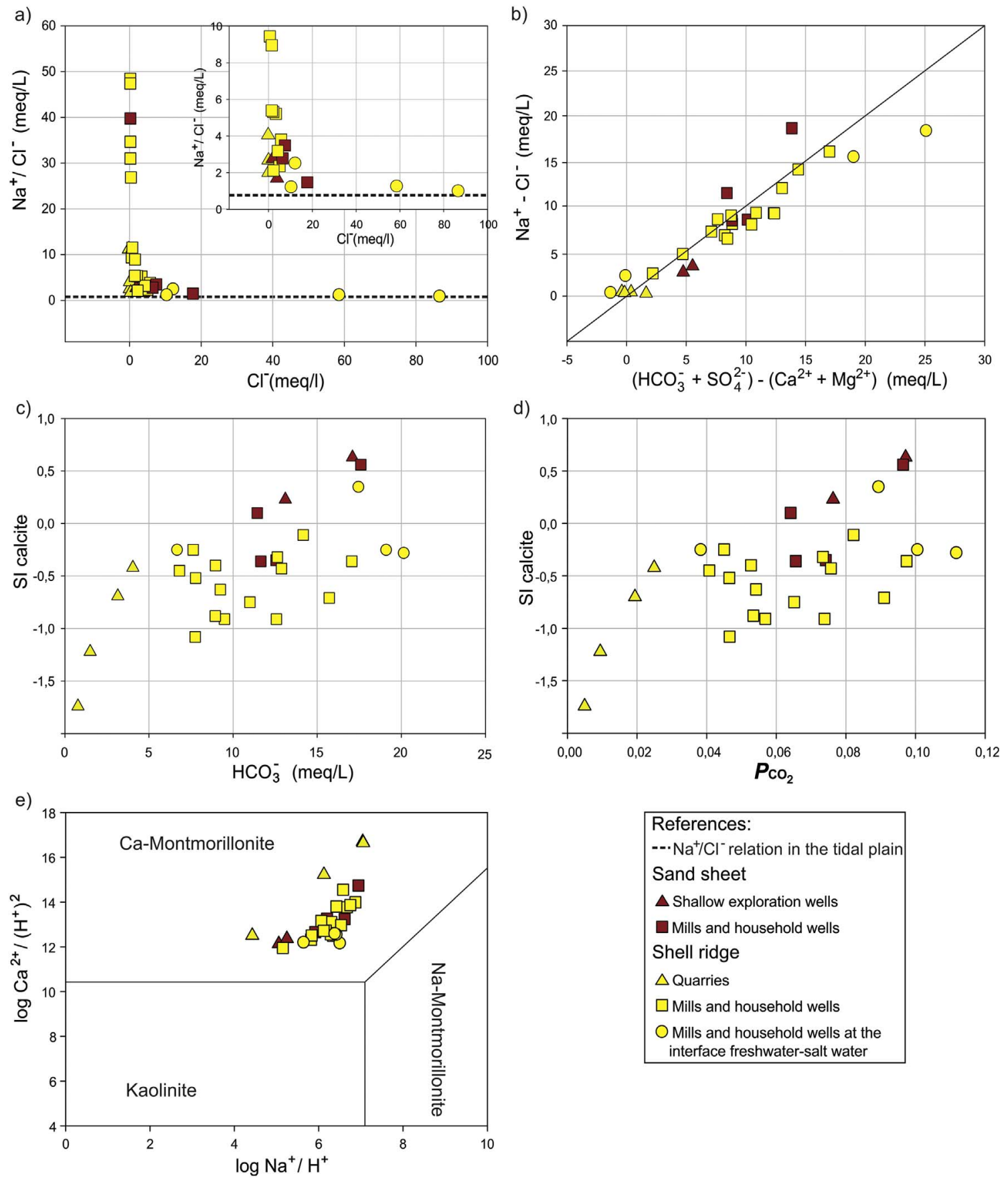

\begin{tabular}{|l|}
\hline References: \\
$-\cdots \mathrm{Na}^{+} / \mathrm{Cl}^{-}$relation in the tidal plain \\
Sand sheet \\
$\Delta$ Shallow exploration wells \\
$\square$ Mills and household wells \\
Shell ridge \\
$\triangle$ Quarries \\
$\square$ Mills and household wells \\
O Mills and household wells at the \\
interface freshwater-salt water \\
\hline
\end{tabular}

Fig. 4. Ratios between major ions and saturation indices (a to d); Clay minerals stability graph (e).

registered in these samples (SI calcite between -1.73 and -0.41) (Fig. 4c), increasing its value as the $\mathrm{HCO}_{3}{ }^{-}$and $P_{\mathrm{CO} 2}$ content rises (Fig. 4c, d).

Two different types of water can be recognized within the samples obtained from the sand sheets due to differences on the wells depth. On one hand, in the deeper wells (mills and household wells), most of water samples are sodium chloride type, except for one sample that is sodium bicarbonate type (Fig. 3). The $\mathrm{pH}$ ranges between 7.78 and 8.69 and the electrical conductivity reaches values of 827 to $2940 \mu \mathrm{S} / \mathrm{cm}$. In the sodium chloride samples the $\mathrm{Na}^{+} / \mathrm{Cl}^{-}$ratio is close to 3 , while in the sodium bicarbonate is 39.7 (Fig. 4a). On the other hand, the shallow exploration wells present calcium bicarbonate type water, lower $\mathrm{pH}$ values (7.54) and an electrical conductivity generally below $1000 \mu \mathrm{S} /$ cm (Fig. 3), being the $\mathrm{Na}^{+} / \mathrm{Cl}^{-}$ratio near 2 (Fig. 4a).

It is observed that for the set of samples gathered in the sand sheets the stable mineral from the group of the smectites is Ca-montmorillonite (Fig. 4e) and the SI calcite trends to increase from undersatured to satured values as the $\mathrm{HCO}_{3}{ }^{-}$and $P_{\mathrm{CO} 2}$ rises (Fig. 4c, d). All the samples show $\mathrm{Na}^{+}$excess that, in some of them, tends to be higher than the $\mathrm{Ca}^{2+}$ and $\mathrm{Mg}^{2+}$ deficiencies (Fig. 4b).

The morphology of the freshwater lenses was determined using a local perpendicular monitoring network established by 7 wells, which include both, shallow and deeper water samples. This network has been monitored since 2014, but in this paper we used the salinity data obtained in February and October 2015 and September 2016 (Fig. 5). For these years, the water balance shows that 2015 was a wet year, with a mean annual precipitation of $1059 \mathrm{~mm}$ and an actual evapotranspiration of $796 \mathrm{~mm}$, on the contrary, 2016 shows values of $803 \mathrm{~mm}$ and $696 \mathrm{~mm}$ respectively, considered as a dry year.

The salinity values prove that the freshwater lens (EC lower than 


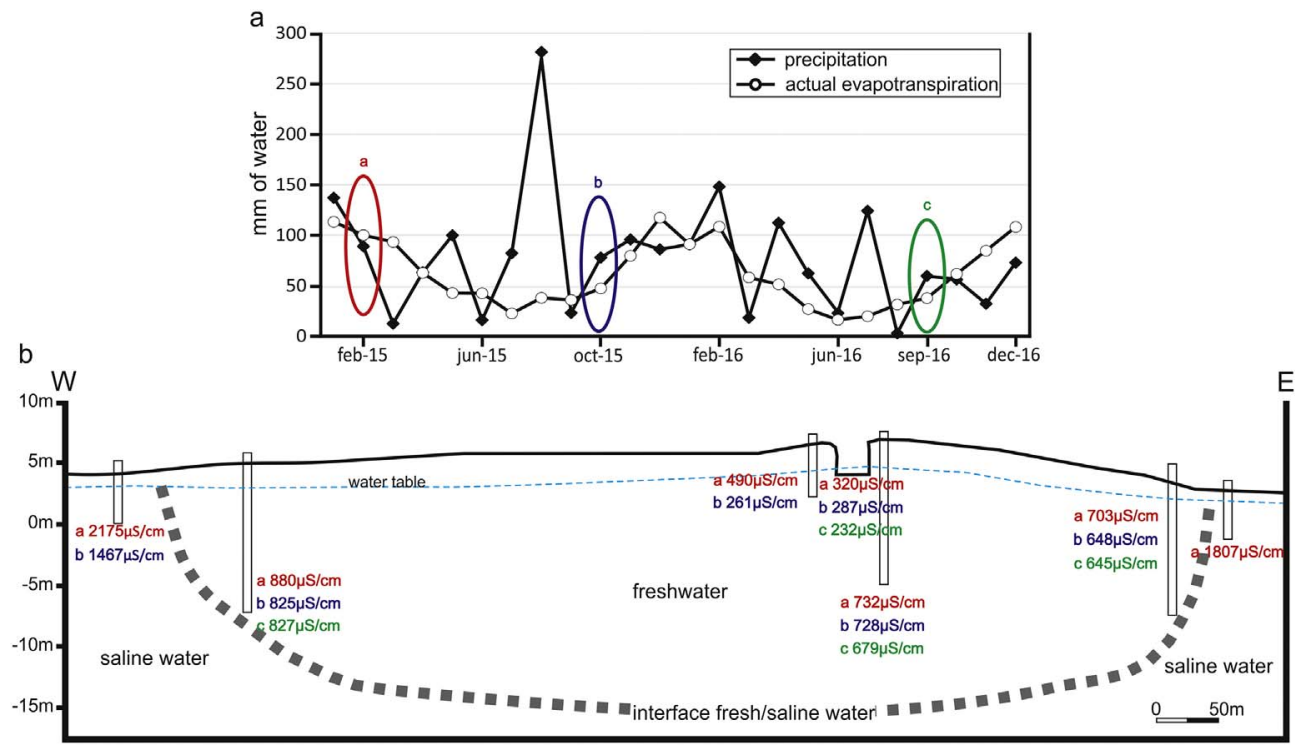

Fig. 5. Water balance for the 2015-2016 period and sampling periods. Hydrogeological profile of the freshwater lens with salinity data for each sampling period.

$900 \mu \mathrm{S} / \mathrm{cm})$ is confined to the high-permeability geoforms, which contain it and abruptly wedged towards the coastal plain (Fig. 5). Inside the lens, salinity fluctuates between 232 and $880 \mu \mathrm{S} / \mathrm{cm}$ with the lowest values at the most superficial sectors. On the other side, in the adjacent coastal plain the EC increases to $2100 \mu \mathrm{S} / \mathrm{cm}$, indicating the interface limit. Note that the saline content of all the wells tends to slightly decrease during larger precipitation periods (October 2015 and September 2016).

It is important to highlight that the obtained results show that small geoforms, like ridges or sand sheets, allow the existence of freshwater lenses within a saline groundwater dominated wetland. The vertical movements of water against the horizontals are favored due to the lowhydric gradient (of $10^{-6}$ order). As a consequence, rainwater infiltration preferentially happens in the more permeable sediments of the ridges and sand sheets. Meanwhile, in the silty- to clay-grained adjacent coastal plain, seepage is low and during rains water tends to be accumulated on the surface. Therefore the morphology of the lenses matches with that of the ridges and sheets, being the fresh - saline water interface next to the adjacent coastal plain. Nevertheless, in depth the lenses extends beyond the formations comprising these geoforms registering that the fresh-saline water interface can reach depths up to $8 \mathrm{~m}$ in the sand sheets and $12 \mathrm{~m}$ in the ridges (Fig. 5). Dimensions, topography and lithological variations of these geoforms may alter this depth (Schneider and Kruse, 2003), being very thin those accumulated in smaller ridges and sheets.

Freshwater lenses in Samborombón Bay play an important role within the wetland. On one hand, they have an ecological importance since they are the sustenance of the native forest of Celtis tala that along with species of Scutia buxifolia and Jodina rhombifolia are the only native tree species of the wetland. A combination of well-drained soils into the sand sheets and shell ridges with freshwater harbored in the lenses enables the existence of this woodland. This native forest has a great biodiversity and is a source of countless ecosystem goods such as habitat for wetland native species, whereabouts and breeding place of birds, wood supply for the local inhabitants, etc. (Canevari et al., 1998). On the other hand, freshwater lenses also constitute the only source of potable water for the rural villagers of the wetland. Although shell ridges and sand sheets are numerous within the wetland, individually they are minor geoforms with scarce areal extension whose reserves are limited. Inside each lens the underground flow has short paths from the crest of the lens to the adjacent coastal plain, dominated by the vertical flow. Under these conditions, it is expected that most of the dissolved ions in the groundwater lenses are acquired during rainwater seepage in the UZ (unsaturated zone) and to a lesser extent by the contact with the sedimentary matrix of the aquifer (Appelo and Postma, 2005). Ions brought to water by this interaction do not tend to affect its potability, registering only a few cases associated with volcanic glass dissolution and addition of As and $\mathrm{F}^{-}$(Carol et al., 2015).

If the water-mineral interaction is analyzed, in both sand sheets and shell ridges, the sandy fraction is primarily composed by quartz, plagioclase and carbonates (shells), whit amphiboles in a lesser proportion. Quartz dominates in the sand sheets whereas carbonates in the shell ridges. The lenses are directly recharged by rainfall recorded during the whole year on the area. $\mathrm{CO}_{2(\mathrm{~g})}$ on the atmosphere and in the UZ pore sediments reacts with rainwater generating $\mathrm{HCO}_{3}{ }^{-}$ and $\mathrm{H}^{+}$ions (Eq. (1)). This reaction decreases $\mathrm{pH}$ and free $\mathrm{H}^{+}$react with carbonated phases causing its dissolution (Eq. (2)) and hence add $\mathrm{Ca}^{+2}$ and $\mathrm{HCO}_{3}{ }^{-}$ions to groundwater increasing the SI calcite. Considering that this reaction consumes $\mathrm{H}^{+}, \mathrm{pH}$ tends to rise, however the UZ regains its acidity by dissolving more $\mathrm{CO}_{2(\mathrm{~g})}$ which can be originated from roots, decomposition of organic matter on the soil or the atmosphere (Eq. (3)). As the dissolution of carbonates consumes $\mathrm{H}^{+}$ and $\mathrm{CO}_{2(\mathrm{~g})}$ the acidity in the saturated zone is loosen, not being able to incorporate $\mathrm{CO}_{2(\mathrm{~g})}$ to the system, and diminishes its capacity of dissolving and altering carbonates (Hem, 1985; Appelo and Postma, 2005) accordingly the SI calcite is stabilized. Note that SI increases from the superficial samples represented by the quarries to a relatively constant value in the deeper samples of the ridges (Fig. 4c). A slightly increase in $P_{\mathrm{CO} 2}$ favors $\mathrm{CO}_{2(\mathrm{~g})}$ dissolution, which not only contributes to carbonate dissolution but also is responsible of the weathering of silicates (Berg and Banwart, 2000).

$\mathrm{CO}_{2}+\mathrm{H}_{2} \mathrm{O} \leftrightarrow \mathrm{HCO}_{3}^{-}+\mathrm{H}^{+}$

$\mathrm{CaCO}_{3}+\mathrm{H}^{+} \leftrightarrow \mathrm{HCO}_{3}^{-}+\mathrm{Ca}^{2+}$

$\mathrm{CH}_{2} \mathrm{O}+\mathrm{O}_{2} \rightarrow \mathrm{CO}_{2}+\mathrm{H}_{2} \mathrm{O}$

The plagioclase and amphibole of the sandy fraction are altered to kaolinite and/or montmorillonite by hydrolysis (Eqs. (4)-(7)), adding $\mathrm{Na}^{+}$ions into groundwater. Plagioclases are solid solutions that can present intermediate compositions between calcium (anortite) and sodium ends (albite). Eq. (5) shows the general hydrolysis of plagioclases, where $x$ is the anortite proportion and $y$ is the amount of $\mathrm{Al}^{3+}$ provided by other feldspars weathering (Velbel, 1992), in this particular case we present the hydrolysis of albite to Na-montmorillonite and kaolinite (Eqs. (6) and (7)). 


$$
\begin{aligned}
& 2 \mathrm{NaCa}_{2} \mathrm{Mg}_{4}\left(\mathrm{Al}_{0.8}, \mathrm{Fe}_{0.2}\right)\left(\mathrm{Si}_{3.75}, \mathrm{Al}_{0.25}, \mathrm{O}_{11}\right)_{2}+3 \mathrm{H}_{2} \mathrm{O}+22 \mathrm{H}^{+}+0.5 \mathrm{O}_{2} \\
& \rightarrow \mathrm{Na}\left(\mathrm{Al}_{1.3}, \mathrm{Fe}_{0.2}, \mathrm{Mg}_{0.5}\right) \mathrm{Si}_{4} \mathrm{O}_{10}(\mathrm{OH})_{2}+\mathrm{Ca}_{0.5}\left(\mathrm{Al}_{1.3}, \mathrm{Fe}_{0.2}, \mathrm{Mg}_{0.5}\right) \mathrm{Si}_{4} \mathrm{O}_{10} \\
&(\mathrm{OH})_{2}+7 \mathrm{H}_{4} \mathrm{SiO}_{4}+7 \mathrm{Mg}^{2+}+3.5 \mathrm{Ca}^{2+}+\mathrm{Na}^{+}
\end{aligned}
$$

$\mathrm{Ca}_{x} \mathrm{Na}_{(1-x)} \mathrm{Al}_{(1+\mathrm{x})} \mathrm{Si}_{(3-x)} \mathrm{O}_{8}+[4.5-3.5 x+2.5 y(1+x)] \mathrm{H}_{2} \mathrm{O}+(1+x) \mathrm{H}^{+}$

$\rightarrow x \mathrm{Ca}^{2+}+(1-x) \mathrm{Na}^{+}+[(2-2 x)+y(1+x)] \mathrm{H}_{4} \mathrm{SiO}_{4(a q)}$

$+(1+x) y \mathrm{Al}(\mathrm{OH})_{3}+0.5(1+x)(1-y) \mathrm{Al}_{2} \mathrm{Si}_{2} \mathrm{O}_{5}(\mathrm{OH})_{4}$

$3 \mathrm{Na}\left(\mathrm{AlSi}_{3}\right) \mathrm{O}_{8}+\mathrm{Mg}^{2+}+4 \mathrm{H}_{2} \mathrm{O} \rightarrow 2 \mathrm{Na}_{0.5}\left(\mathrm{Al}_{1.5}, \mathrm{Mg}_{0.5}\right) \mathrm{Si}_{4} \mathrm{O}_{10}(\mathrm{OH})_{2}$

$$
+2 \mathrm{Na}^{+}+\mathrm{H}_{4} \mathrm{SiO}_{4}
$$

$2 \mathrm{Na}\left(\mathrm{AlSi}_{3}\right) \mathrm{O}_{8}+2 \mathrm{H}^{+}+9 \mathrm{H}_{2} \mathrm{O} \rightarrow \mathrm{Al}_{2} \mathrm{Si}_{2} \mathrm{O}_{5}(\mathrm{OH})_{4}+2 \mathrm{Na}^{+}+\mathrm{H}_{4} \mathrm{SiO}_{4}$

According to silicates stability graph (Fig. 4e) the stable clay mineral to the water composition is Ca-montmorillonite (Muñóz et al., 1996). Ion exchange explains why Ca-montmorillonite is the stable mineral instead of Na-montmorillonite predicted by reaction (6) (Eq. (8)). All the groundwater samples have $\mathrm{Na}^{+}$excesses related to $\mathrm{Ca}^{2+}$ and $\mathrm{Mg}^{2+}$ deficiencies in a 1:1 ratio, indicating that dissolved $\mathrm{Ca}^{2+}$ and $\mathrm{Mg}^{2+}$ in the water is exchangeable by $\mathrm{Na}^{+}$adsorbed in the clayey phases (Kortatsi, 2006; Carol and Kruse, 2012). However, as ion exchange is practically null in groundwater surfaced on the quarries, water tends to be calcium bicarbonate type (Fig. 4b).

$$
\begin{aligned}
& {\left[\mathrm{Na}-\left(\mathrm{Al}_{1.5}, \mathrm{Mg}_{0.5}\right) \mathrm{Si}_{4} \mathrm{O}_{10}(\mathrm{OH})_{2}\right]+\frac{1}{2} \mathrm{Ca}^{2+}} \\
& \quad \leftrightarrow\left[\mathrm{Ca}_{0.5}-\left(\mathrm{Al}_{1.5}, \mathrm{Mg}_{0.5}\right) \mathrm{Si}_{4} \mathrm{O}_{10}(\mathrm{OH})_{2}\right]+\mathrm{Na}^{+}
\end{aligned}
$$

According to the data obtain for the period 2015-2016 (Fig. 5), there is no significant chemical and/or level changes in the lenses between wet and dry periods. Nevertheless, it cannot be excluded that major changes can occur in longer dry periods, situation previously cited for the region (Carol et al., 2014). It should be noted that even though these lenses are the main sustenance of native species of the wetland and inhabitants of the area, they are threatened by human activities such as shell extraction by mining (Carol et al., 2015). This economic activity is responsible of the clearance, soil removal and UZ using water from the lenses to wash the extracted material. For all these, serious problems in the ecosystem and water reserves have been made by these factories.

Finally, the study of morphology and geochemistry of the freshwater lenses in the Samborombón Bay wetland bring lights into important information about the management of water resources in one of the biggest RAMSAR areas of South America. As worldwide happens, the coastal wetlands are intensely degraded by human activities, which caused the loss of essential ecosystemic functions (Brinson and Malvárez, 2002; Hernández-Romero et al., 2004; Benito et al., 2015). The preservation of freshwater lenses in wetlands should be of importance for the all the National governs, as they provide an irreplaceable ecosystem and a vital source of water for the local populations.

\section{Acknowledgements}

The authors are very indebted to the Agencia Nacional de Promoción Científica y Tecnológica (National Agency for Scientific and Technological Promotion), the Consejo Nacional de Investigaciones Científicas y Técnicas (National Council for Scientific and Technological Research), and the Universidad Nacional de La Plata (National University of La Plata) of Argentina for financially supporting this study by means of their grants, PICT 2013-2248 and PID N782.

\section{References}

APHA (American Public Health Association), 1998. Standard Methods for the Examination of Water and Wastewater, Twentieth ed. American Public Health Association, American Water Works Association, Water Environment Federation, Washington, DC.

Appelo, C., Postma, D., 2005. Geochemistry, Groundwater and Pollution, second ed. Balkema Publishers.

Benito, X., Trobajo, R., Ibáñez, C., Cearreta, A., Brunet, M., 2015. Benthic foraminifera as indicators of habitat change in anthropogenically impacted coastal wetlands of the Ebro Delta (NE Iberian peninsula). Mar. Pollut. Bull. 101, 163-173.

Berg, A., Banwart, S., 2000. Carbon dioxide mediated dissolution of Ca-feldspar: implications for silicate weathering. Chem. Geol. 163, 25-42.

Brinson, M.M., Malvárez, A.I., 2002. Temperate freshwater wetlands: types, status, and threats. Environ. Conserv. 29, 115-133.

Canevari, P., Blanco, D.E., Bucher, E., Castro, G.Y., Davidson, I., 1998. Los humedales de la Argentina. Clasificación, situación actual, conservación y legislación. (Publicación No. 46) Wetlands International, Buenos Aires, Argentina.

Carol, E., Kruse, E., 2012. Hydrochemical characterization of the water resources in the coastal environments of the outer Río de la Plata estuary, Argentina. J. S. Am. Earth Sci. 37, 113-121.

Carol, E., Kruse, E., Mas Pla, J., 2009. Hydrochemical and isotopical evidence of groundwater salinization processes on the coastal plain of Samborombón Bay, Argentina. J. Hydrol. 365, 335-345.

Carol, E., Kruse, E., Roig, A., 2010. Groundwater travel time in the freshwater lenses of Samborombón Bay, Argentina. Hydrol. Sci. J. 55, 754-762.

Carol, E., Braga, F., Kruse, E., Tosi, L., 2014. A retrospective assessment of the hydrological conditions of the Samborombón coastland (Argentina). Ecol. Eng. 67, 223-237.

Carol, E., García, L., Borzi, G., 2015. Hydrogeochemistry and sustainability of freshwater lenses in the Samborombón Bay wetland, Argentina. J. S. Am. Earth Sci. 60, 21-30.

Carol, E.S., Alvarez, M., Borzi, G.E., 2016. Assessment of factors enabling halite formation in a marsh in a humid temperate climate (Ajó Marsh, Argentina). Mar. Pollut. Bull. 106, 323-328.

De Louw, P., Eeman, S., Siemon, B., Voortman, B., Gunnink, J., Van Baaren, E., Oude Essink, G., 2011. Shallow rainwater lenses in deltaic areas with saline seepage. Hydrol. Earth Syst. Sci. 15, 3659.

Fletcher, S., Kawabe, M., Rewhorn, S., 2011. Wetland conservation and sustainable coastal governance in Japan and England. Mar. Pollut. Bull. 62, 956-962.

Hem, J., 1985. Study and interpretation of the chemical characteristics of natural water. In: US Geological Survey Water Supply Paper 2254.

Hernández-Romero, A.H., Tovilla-Hernández, C., Malo, E.A., Bello-Mendoza, R., 2004. Water quality and presence of pesticides in a tropical coastal wetland in southern Mexico. Mar. Pollut. Bull. 48, 1130-1141.

Kortatsi, B., 2006. Hydrochemical characterization of groundwater in the Accra plains of Ghana. Environ. Geol. 50, 299-311.

Maas, K., 2007. Influence of climate change and sea level rise on a Ghyben-Hersberg lens. J. Hydrol. 347, 223-228.

Morgan, L., Werner, A., 2014. Seawater intrusion vulnerability indicators for freshwater lenses in strip islands. J. Hydrol. 508, 22-327.

Muñóz, I., De Andres, A., Vicente, R., 1996. Estabilidad de los minerales de la arcilla en las relaciones de interacción arcosas-agua subterránea en el acuífero de Campo Arañuelo. Geogaceta 20, 1307-1310.

Odum, W., Harvey, J., 1988. Barrier island interdunal freshwater wetlands. Assoc. South. Biol. Bull. 35, 149-155.

Schneider, J., Kruse, S., 2003. A comparison of controls on freshwater lens morphology of small carbonate and siliciclastic islands: examples from barrier islands in Florida, USA. J. Hydrol. 284, 253-269.

Thornthwaite, C.W., Mather, J.R., 1957. Instructions and tables for computing potential evapotranspiration and the water balance. Publ. Climatol. 10, 185-311.

Velbel, M., 1992. Geochemical mass balances and weathering rates in forested watersheds of the southern Blue Ridge, III. Cation budgets and the weathering rate of amphibole. Am. J. Sci. 292, 58-78. 